oyster Crassostrea gigas. In: Hylland, K., Lang, T., Thain, J., Vethaak, A.D., Wosniok, W. (Eds.), Biological Effects of Contaminants in Pelagic Ecosystems. Society of Environmental Toxicology and Chemistry (SETAC), Brussels, pp. 367-376.

Manly, B.F.J., 1998. Randomization, Bootstrap and Monte Carlo Methods in Biology, second ed. Chapman and Hall, London, 399 pp.

McCloskey, J.T., Oris, J.T., 1993. Effect of anthracene and solar ultraviolet radiation exposure on gill ATPase and selected hematological measurements in bluegill sunfish (Lepomis macrochirus). Aquatic Toxicology 24, 207-218.

Morris, D.P., Zagarese, H., Williamson, C.E., Balserio, E.G., Hargreaves, B.R., Modenutti, B., Moeller, R., Queimalinos, C., 1995. The attenuation of solar UV radiation in lakes and the role of dissolved organic carbon. Limnology and Oceanography 40, 1381-1391.

Peachey, R.B.J., 2005. The synergism between hydrocarbon pollutants and UV radiation: a potential link between coastal pollution and larval mortality. Journal of Experimental Marine Biology and Ecology 315, $103-114$.
Pelletier, M.C., Burgess, R.M., Ho, K.T., Kuhn, A., McKinney, R.A., Ryba, S.A., 1997. Phototoxicity of individual polycyclic aromatic hydrocarbons and petroleum to marine invertebrate larvae and juveniles. Environmental Toxicology and Chemistry 16, 21902199.

Stagg, R.M., 1998. The development of an international programme for monitoring the biological effects of contaminants in the OSPAR convention area. Marine Environmental Research 46, 307-313.

Wernersson, A.-S., 2003. Predicting petroleum phototoxicity. Ecotoxicology and Environmental Safety 54, 355-365.

Westernhagen, H.V., Landolt, M., Kocan, R., Furstenberg, G., Janssen, D., Kremling, K., 1987. Toxicity of Sea-surface microlayer: effects on herring and turbot embryos. Marine Environmental Research 23, 273 290.

Williamson, C.E., Stemberger, R.S., Morris, D.P., Frost, T.M., Paulsen, S.G., 1996. Ultraviolet radiation in North American lakes: attenuation estimates from DOC measurements and implications for plankton communities. Limnology and Oceanography 41, 1024-1034.

\title{
Mercury contamination in invertebrate biota in a temperate coastal lagoon (Ria de Aveiro, Portugal)
}

\author{
J.P. Coelho $^{\text {b,* }}{ }^{\text {, E. Policarpo }}{ }^{\text {a }}$, M.A. Pardal ${ }^{\text {c }}$, G.E. Millward ${ }^{\text {a }}$, M.E. Pereira ${ }^{\text {b }}$, A.C. Duarte ${ }^{\text {a }}$

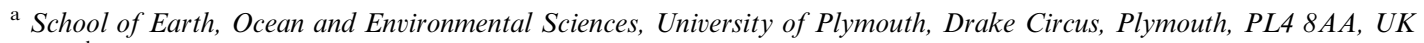 \\ ${ }^{\mathrm{b}}$ CESAM - Chemistry Department, University of Aveiro, Campus de Santiago, 3810-193 Aveiro, Portugal \\ ${ }^{\mathrm{c}}$ IMAR - Institute of Marine Research, Zoology Department, University of Coimbra, 3004-517 Coimbra, Portugal
}

Mercury is an element that has both natural and anthropogenic sources (OSPAR, 2004). Given the significant inputs of mercury to the environment, this metal is considered a "blacklisted" pollutant in terms of environmental damage and a threat to human health. Its high mobility, persistence in the environment, and lipophilicity, justify the importance of the environmental study of mercury, as it is a toxic element to all living organisms (Boening, 2000).

The Ria de Aveiro (Fig. 1), situated on the northern coast of Portugal and with a total area ranging from 83 (high tide) to $66 \mathrm{~km}^{2}$ (low tide) (Dias et al., 2001) has, for the past five decades, received continuous discharges of a mercury-rich effluent from a chlor-alkali factory. This situation led to widespread contamination of sediments, water and biota of the area, and created a well defined anthropogenic mercury gradient in the system. Research on the fate and behavior of mercury in the nearby area of the discharge has so far focused mainly on identifying the major impacted areas, quantifying the level of contamination and assessing the response of mercury to physicochemical changes in sediment and water (Pereira et al.,

\footnotetext{
* Corresponding author. Tel.: +351 234370737; fax: +351 234370084.

E-mail address: jcoelho@dq.ua.pt (J.P. Coelho).
}

1998a,b). Determinations of mercury concentrations in marine biota are limited to plankton (Monterroso et al., 2003), estuarine macroalgae (Coelho et al., 2005) and sea bass (Abreu et al., 2000), hence further work is required on other species, especially edible varieties with economic interest.

The main aim of this work was to assess the mercury accumulation through various trophic levels in locations subject to different contamination levels, and relate it to sediment, water and suspended particulate matter (SPM) mercury concentrations. Moreover, to verify whether mercury accumulation represents any potential risk for public health, economically important macroinvertebrate species placed at different levels of the food web were selected: (a) Nereis diversicolor, (a subsurface deposit feeder) used as fish bait; (b) Scrobicularia plana (a surface deposit feeder) and (c) Carcinus maenas (an omnivore or top predator).

Three locations were selected for sampling, as shown in Fig. 1. The Laranjo Basin corresponds to a highly contaminated area located close to the mercury discharge source, whereas the two other sites, Coroa and Mira, are located at two opposite extremes of the lagoon, respectively the furthest and closest to the estuary mouth.

All samples were collected on a consecutive three-day sampling campaign in the summer of 2003 , at equivalent 


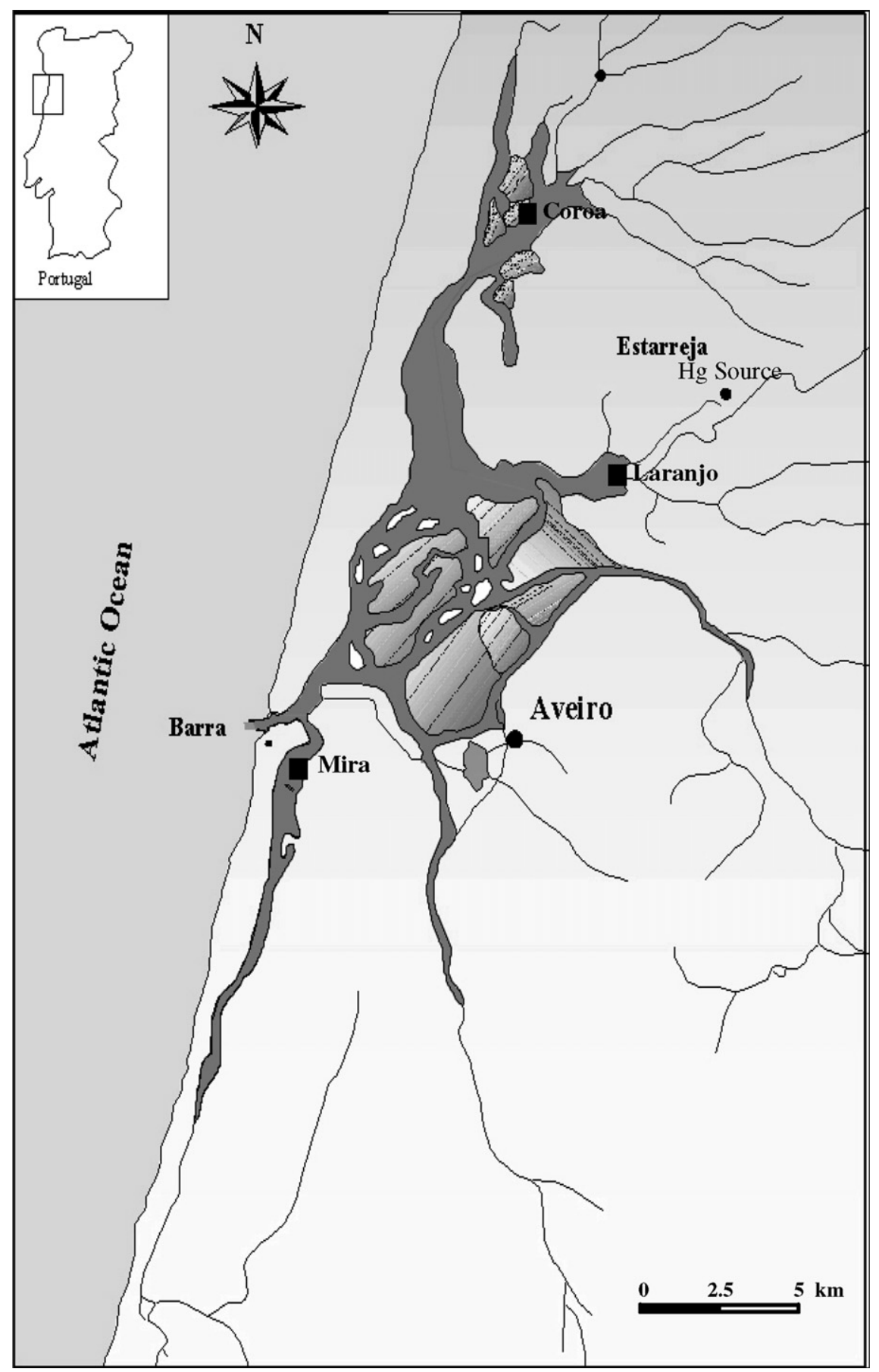

Fig. 1. The Ria de Aveiro system with sampling sites (Laranjo, Coroa and Mira) indicated (

tidal situations. Previous studies (Ramalhosa et al., 2001; Monterroso et al., 2003) reported higher dissolved and particulate mercury levels in low tide conditions $\left(25 \mathrm{ng} \mathrm{L}^{-1}\right.$ in the dissolved fraction and $6.6 \mu \mathrm{g} \mathrm{g}^{-1}$ in the particulate fraction in low tide conditions, as opposed to $10 \mathrm{ng} \mathrm{L}^{-1}$ and $3.5 \mu \mathrm{g} \mathrm{g}^{-1}$ in high tide, in the Laranjo site). Low water conditions were therefore found to better express the maximum potential contamination stress to organisms, and sampling was conducted in accordance. At each site a composite sediment sample was obtained from the oxic-sub- oxic layer $(0-2 \mathrm{~cm})$, consisting of five replicate samples pooled together in order to account for within-site variability. Water samples were collected from intertidal water at each site in acid-washed plastic bottles. Sediments were air-dried for three days and then oven-dried overnight at $60{ }^{\circ} \mathrm{C}$, homogenized and sieved through a $1 \mathrm{~mm}$ sieve. Water samples were filtered on arrival to the laboratory, through $0.45 \mu \mathrm{m}$ Millipore cellulose acetate membrane filters, acidified with $\mathrm{HNO}_{3}$ (to lower the $\mathrm{pH}$ below 2) and stored at $4{ }^{\circ} \mathrm{C}$ until analysis. Filters were oven-dried at 
$60{ }^{\circ} \mathrm{C}$ and digested with $\mathrm{HNO}_{3} 4 \mathrm{~mol} \mathrm{~L}^{-1}$ for determination of the total mercury concentration in the SPM fraction.

Biological samples were collected from the shoreline, and consisted of 10 replicates at each site for $N$. diversicolor and $S$. plana. The biology of $N$. diversicolor in this system was reported by Abrantes et al. (1999), who found the lifespan of this species to range between 12 and 15 months, with an annual growth rate of $\approx 6 \mathrm{~cm} \mathrm{y}^{-1}$, and two recruitment periods, in February and April/May. Samples of $N$. diversicolor ranged between 6 and $7 \mathrm{~cm}$ (about 1-y-old adult individuals) and bias related to reproduction was avoided by sampling outside recruitment periods.

S. plana is a long-lived deposit feeding bivalve species present in muddy to sandy sediments (Verdelhos et al., 2005). It's life cycle in southern Europe is well studied, where it has a lifespan of $5 \mathrm{y}$, one annual recruitment period in spring and growth rates of roughly $1 \mathrm{~cm} \mathrm{y}^{-1}$ (Verdelhos et al., 2005). Sampling focused on 3-y-old adult individuals (about $3 \mathrm{~cm}$ shell width), the smallest commercially available individuals. Bias related to reproduction was avoided by sampling outside the spring recruitment period.

For $C$. maenas, due to the low biomass of the different tissues, a composite sample was prepared of 15 individuals of similar size (around $3.5 \mathrm{~cm}$ width). Sexual maturity in this species is reached at $\approx 3 \mathrm{~cm}$ carapace length, corresponding to $1+$ year-old adult individuals, and the recruitment period extends throughout several months (Baeta et al., 2005). Therefore, in order to minimize uncertainty related to reproductive state, only male individuals were collected.

$S$. plana and $N$. diversicolor samples were left to depurate overnight, freeze-dried at $-50{ }^{\circ} \mathrm{C}$ and 0.06 bars, and homogenized for analysis. C. maenas samples were washed to remove sediment and epiphytes, dissected and freezedried. Three different tissues were considered for analysis (hepatopancreas, gills, muscle), and all analyses were performed in composite samples.

Sediment and biological samples were analyzed for total mercury by thermal decomposition atomic absorption spectrometry with gold amalgamation, using a LECO AMA-254 (Advanced Mercury Analyzer). Dissolved reactive mercury and suspended particulate matter (SPM) mercury analyses were performed by cold-vapor atomic fluorescence spectrometry (CV-AFS) using a PSA model Merlin 10.023 equipped with a detector PSA model 10.003 , with tin chloride as reducing agent $(2 \%$ in $10 \%$ $\mathrm{HCl}$ ). Organic mercury determinations in biological tissues were determined through digestion with a mixture of $18 \%$ $\mathrm{KBr}$ in $5 \% \mathrm{H}_{2} \mathrm{SO}_{4}$, followed by extraction of organic mercury into toluene (for further detail see Válega et al., 2006).

Analytical quality control was performed by using Certified Reference Materials (CRMs) IAEA-356 and MESS-2 (for sediments) and TORT-2 (for biota). The results were corrected according to the daily recovery percentage of the CRM analyses. The values obtained for the whole of the CRM analysis ranged from $77.6 \%$ to $102 \%$ with an average of $90.2 \% \pm 5.3 \%$ (at 0.05 significance level). Analyses of CRMs were always performed in triplicate. Reference material NIST - 2976 was used for organic mercury analyses, and an extraction efficiency range of $75-80 \%$ was achieved.

The results were analysed using one-way ANOVA followed by Tukey's HSD, or its non-parametric equivalent Kruskal-Wallis, followed by Mann-Whitney pair-wise testing (both at 0.05 significance level).

Environmental contamination was found to occur mainly in the vicinity of the contamination source (Fig. 2), where very high levels were observed; mercury levels in biota reflect a similar trend (Fig. 3). A general pattern was observable, with the highest levels found in the very contaminated area of Laranjo and considerably lower values at the other two sites. Furthermore, the three species

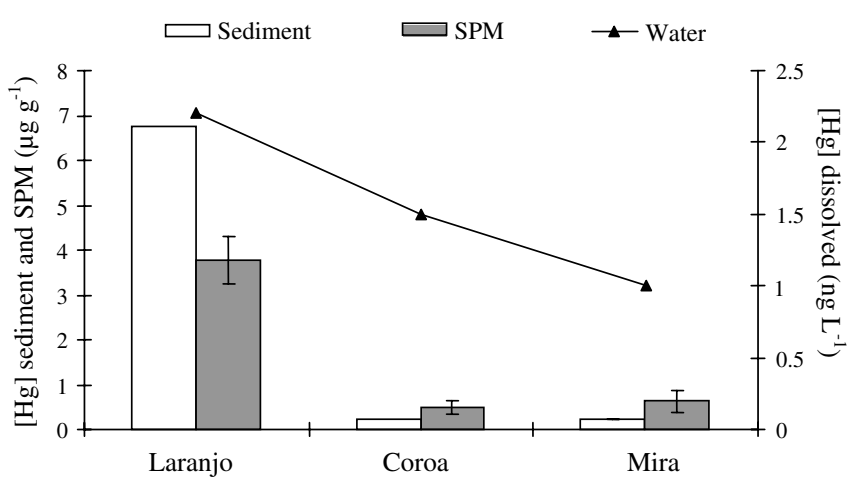

Fig. 2. Total mercury levels in sediments $\left(\mu \mathrm{g} \mathrm{g}^{-1}\right)$, dissolved fraction $\left(\mathrm{ng} \mathrm{L}^{-1}\right)$ and SPM $\left(\mu \mathrm{g} \mathrm{g}^{-1}\right)$ (error bars indicate standard deviation).

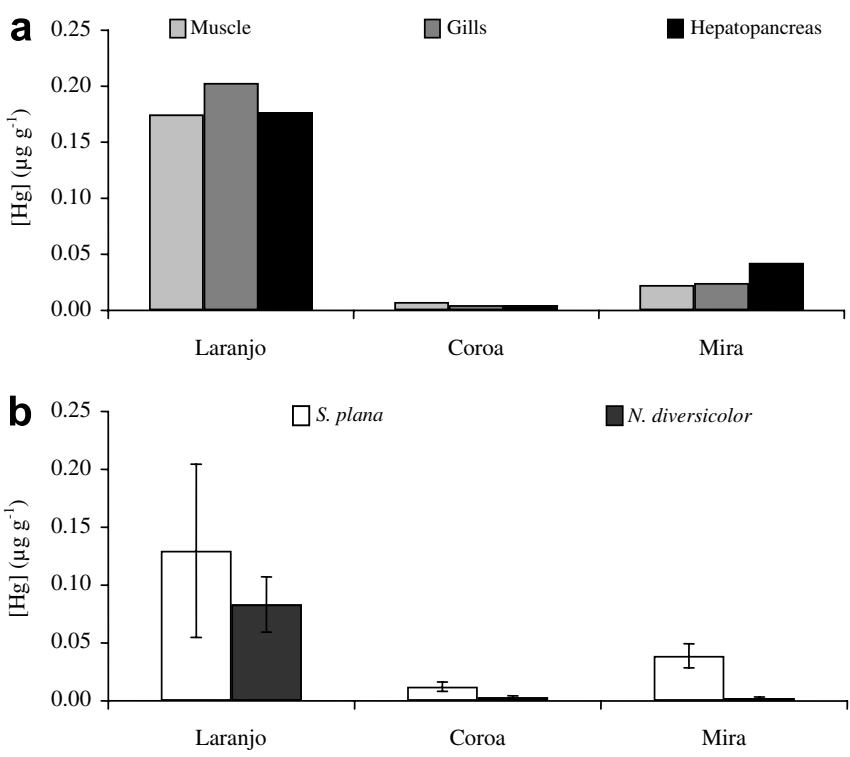

Fig. 3. Total mercury levels ( $\mu \mathrm{g} \mathrm{g}^{-1}$ wet weight) in invertebrate biota: C. maenas tissues (muscle, gills and hepatopancreas) (a); S. plana (soft tissues) and $N$. diversicolor (whole body) (b) (error bars indicate standard deviation). 
showed higher levels of contamination in Mira as compared to Coroa (Mann-Whitney $U$ tests at Coroa and Mira for S. plana, $p<0.001$; and $N$. diversicolor, $p<0.001$ ), despite similar sediment contamination levels. Thus, there is a clear gradation of total mercury levels in biota as follows: Laranjo $>$ Mira $>$ Coroa.

The higher biota contamination found in Mira as opposed to the similarly contaminated Coroa site may be related to the hydrodynamics of the system, which are responsible for the transport of fine metal-rich particles, which in turn may be consumed by the biota (surface and subsurface deposit feeders). These particles are transported seawards with the flow, away from the Coroa area and towards Mira, where they may deposit. This hypothesis is consistent with the SPM mercury concentrations found and is a possible explanation for the higher mercury contamination levels in organisms from the Mira site.

C. maenas has the highest average total mercury levels of the three species (Fig. 3a), even though the highest mercury level was found in an individual S. plana sample in the Laranjo basin (Fig. 3b), where standard deviation was quite high. $N$. diversicolor was the species least responsive to mercury. Species-specific factors may explain the difference in bioaccumulation processes. These include feeding techniques and the medium from which most feeding is undertaken, or adaptation to high mercury concentrations and ability to excrete or detoxify the metal as an adaptation mechanism. Boisson et al. (1998) showed that in the bivalve $M$. balthica, individuals sampled in polluted areas had lower mercury uptake rates than those sampled in relatively pristine areas, which suggested an adaptive trait for survival in contaminated areas. Boisson et al. (1998), proposed the adaptation to be at the genetic, cellular, or biochemical levels, since the accumulation potential of the clam was the same in the different sites. Thus this hypothesis may explain the lower mercury bioaccumulation in highly contaminated areas such as the Laranjo basin. This feature has also been observed in previous studies for the oligochaete $T$. tubifex, for which tolerance, resistance to mercury and the genetic inheritance of this trait have been reported (Vidal and Horne, 2003).

Organic mercury results were consistent with total mercury content, given that $S$. plana and $N$. diversicolor were less contaminated than $C$. maenas, both in absolute concentrations (maximum $[\mathrm{Hg}]_{\text {org }}$ of $0.03 \mu \mathrm{g} \mathrm{g}^{-1}$ in $N$. diversicolor, $0.07 \mu \mathrm{g} \mathrm{g}^{-1}$ for $S$. plana and up to $0.16 \mu \mathrm{g} \mathrm{g}^{-1}$ in C. maenas) and in the organic mercury fraction (up to $90 \%$ for $C$. maenas, while $S$. plana never exceeded $45 \%$ and $N$. diversicolor 20\%) (Fig. 4a and b). Differences in feeding tactics between the studied species were probably the basis for the different organic mercury loads, lower in the filter feeding, detritivore species ( $S$. plana and $N$. diversicolor) (Fig. 4b). Mercury bioaccumulates up the food web, and predator species (such as C. maenas) will incorporate more mercury through the diet (mainly organic mercury, which bioaccumulates more efficiently) than organisms feeding on detritus with higher total mercury concentrations but
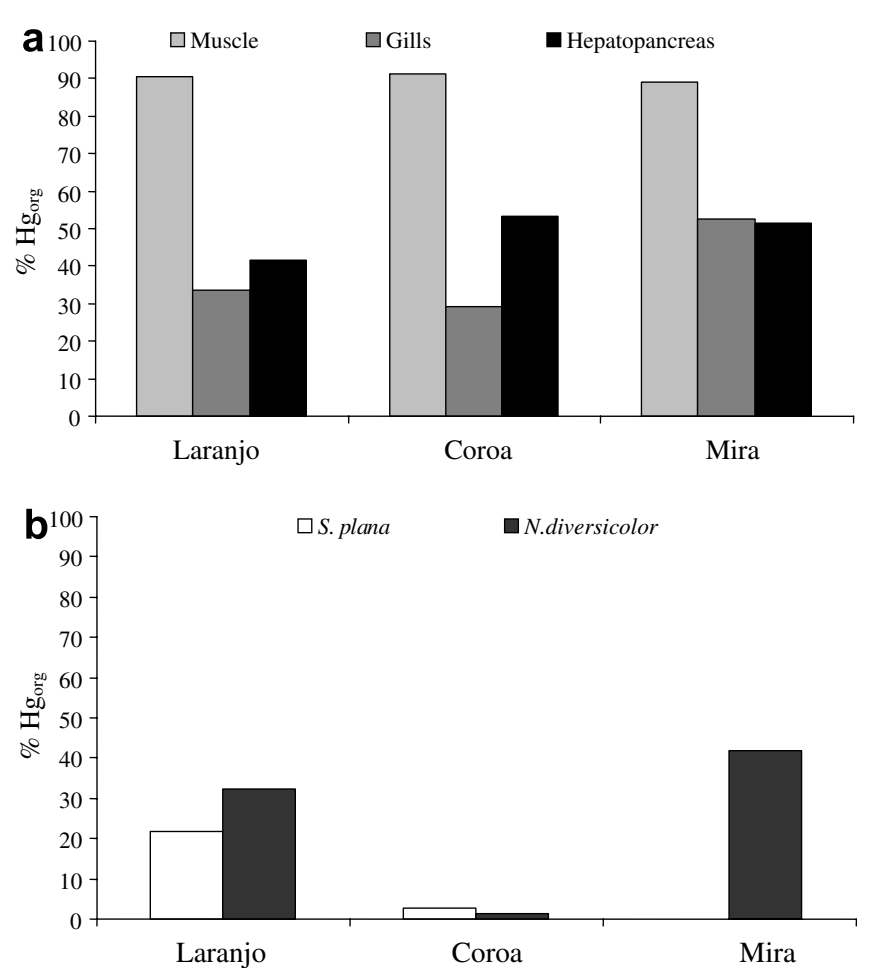

Fig. 4. Percent $\mathrm{Hg}_{\text {org }}$ in invertebrate biota: C. maenas tissues (muscle, gills and hepatopancreas) (a); S. plana (soft tissues) and $N$. diversicolor (whole body) (b).

lower organic mercury concentrations (Watras and Bloom, 1992; Lawson and Mason, 1998).

C. maenas showed differential tissue mercury accumulation, both in total and organic forms (Fig. 3a and 4a). Higher tissue levels were found in the gills in the most contaminated site, shifting to the muscle in Coroa and hepatopancreas in Mira (Fig. 3a). In terms of organic mercury, differential accumulation was again evident, with a higher proportion found in muscle where $[\mathrm{Hg}]_{\text {org }}$ accounts for about $90 \%$ of the total mercury, while in other tissues the proportion never exceeded $55 \%$ of total mercury (Fig. 4a). In previous investigations, the accumulation of mercury was found to take place mainly in the gills (Laporte et al., 1997), but these results derive from a short laboratory study where mercury was added in the dissolved form, hence dietary intake and other factors present in the field were not accounted for. The form in which the mercury is taken in by crabs impacts on its internal fate, and an accumulation in the gills has been associated with a higher intake of inorganic mercury, as the gills are in contact mostly with the dissolved species in water (Laporte et al., 1997). It was observed in our study that the importance of the gills as a bioaccumulation agent is higher in the most contaminated site $([\mathrm{Hg}]$ gills/[Hg]muscle and $[\mathrm{Hg}]$ gills/ $/ \mathrm{Hg}]$ hepatopancreas was superior in this site, hence a higher proportion of $\mathrm{Hg}$ was accumulated in the gills), and decreased in low contamination sites. These results are consistent with the observed dissolved fraction mercury levels. In the least contaminated sites, a higher 
content of total and organic mercury in other body tissues, such as the muscle, suggests that the main source of mercury to the crabs may be under the form of organic and lipophilic mercury, probably from dietary intake.

Bioaccumulation (concentration factor $(\mathrm{CF})=$ wet weight concentration of biota/dry weight concentration of sediment; Williams et al., 1998), is shown in Fig. 5. The mercury $\mathrm{CF}$ for each species appear to be higher in Mira, which means that the three invertebrate species proportionately uptake more mercury at this site. Statistical analyses showed that for each species, CFs differ between sites. S. plana and C. maenas average CFs at Coroa and Laranjo do not differ significantly, whereas Mira differs from the two other sites. For $N$. diversicolor, all sites differ significantly from each other, also indicating a higher $\mathrm{CF}$ at Mira.

Related to the levels of contamination of the different species (illustrated in Fig. 3), this shows that even if the invertebrate species accumulated more metal at the most contaminated site (Laranjo), the proportion of mercury taken up relative to sediment contamination was highest at Mira, and lower and not significantly different at Coroa and Laranjo.
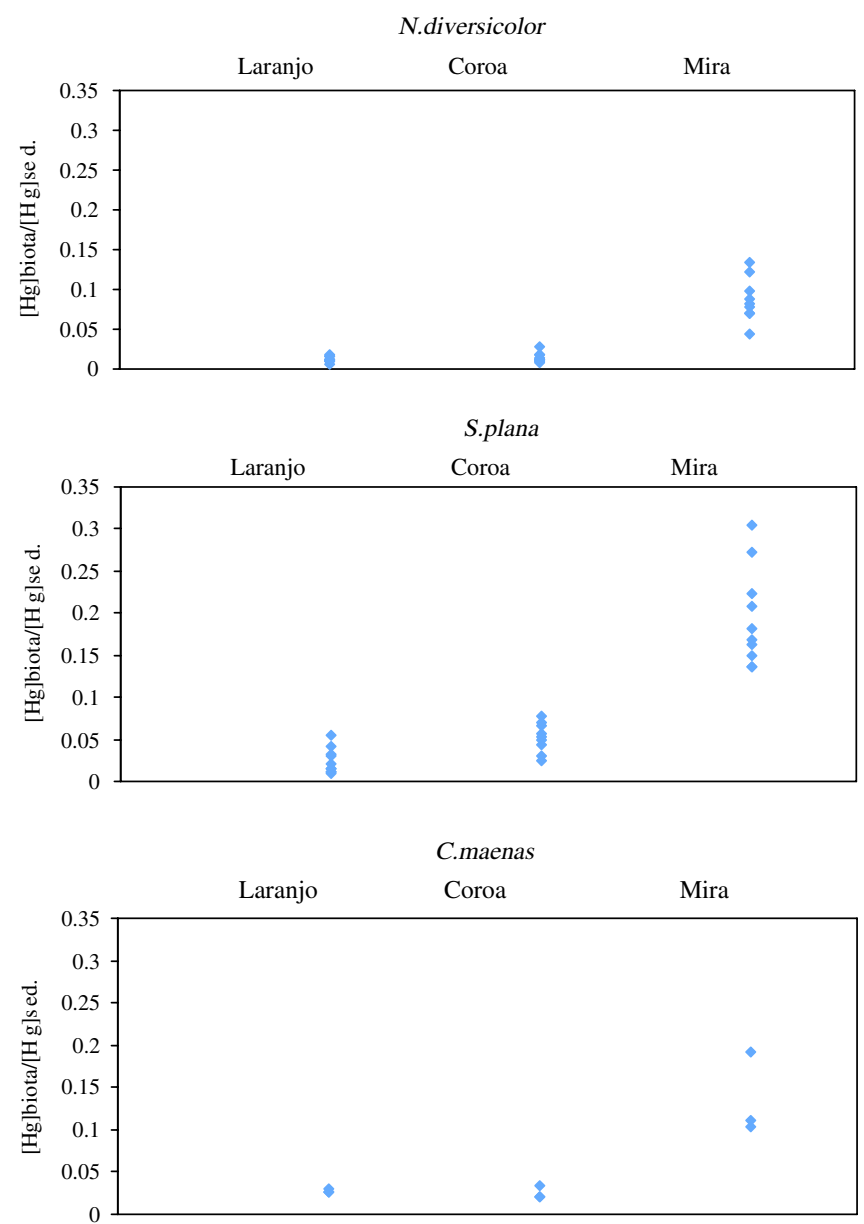

Fig. 5. Concentration factors for the three species and sites $(\mathrm{CF}=$ $\left.[\mathrm{Hg}]_{\text {biota }} /[\mathrm{Hg}]_{\text {sediment }}\right)$.
Calculations of wet weight mercury concentrations in the biological samples show that although all results fall below maximum metal levels permitted for human consumption $\left(0.5 \mu \mathrm{g} \mathrm{g}^{-1}\right.$ wet weight, Regulation (EC) $466 /$ 2001), the levels in the highly contaminated area of Laranjo fall between 0.17 and $0.37 \mu \mathrm{g} \mathrm{g}^{-1}$, a considerably high range, which justifies regular monitoring of the area.

\section{References}

Abrantes, A., Pinto, F., Moreira, M.H., 1999. Ecology of the polychaete Nereis diversicolor in the canal de Mira (Ria de Aveiro, Portugal): Population dynamics, production and oogenic cycle. Acta Oecologica 20, 267-283.

Abreu, S.N., Pereira, E., Vale, C., Duarte, A.C., 2000. Accumulation of mercury in sea bass from a contaminated lagoon (Ria de Aveiro, Portugal). Marine Pollution Bulletin 40, 293-297.

Baeta, A., Cabral, H.N., Neto, J.M., Marques, J.C., Pardal, M.A., 2005. Biology, population dynamics and secondary production of the green crab Carcinus maenas (L.) in a temperate estuary. Estuarine, Coastal and Shelf Science 65, 43-52.

Boening, D.W., 2000. Ecological effects, transport, and fate of mercury: a general review. Chemosphere 40, 1335-1351.

Boisson, F., Hartl, M.G.J., Fowler, S.W., Amiard-Triquet, C., 1998. Influence of chronic exposure to silver and mercury in the field on the bioaccumulation potential of the bivalve Macoma balthica. Marine Environmental Research 45, 325-340.

Coelho, J.P., Pereira, M.E., Duarte, A., Pardal, M.A., 2005. Macroalgae response to a mercury contamination gradient in a temperate coastal lagoon (Ria de Aveiro, Portugal). Estuarine, Coastal and Shelf Science $65,492-500$.

Dias, J.M., Lopes, J.F., Dekeyser, I., 2001. Lagrangian transport of particles in Ria de Aveiro Lagoon, Portugal. Physics and Chemistry of the Earth (B) 26, 721-727.

Laporte, J.M., Truchot, J.P., Ribeyre, F., Boudou, A., 1997. Combined effects of water $\mathrm{pH}$ and salinity on the bioaccumulation of inorganic Mercury and Methylmercury in the shore crab Carcinus maenas. Marine Pollution Bulletin 34, 880-893.

Lawson, N.M., Mason, R.P., 1998. Accumulation of mercury in estuarine food chains. Biogeochemistry 40, 235-247.

Monterroso, P., Abreu, S.N., Pereira, E., Vale, C., Duarte, A.C., 2003. Estimation of $\mathrm{Cu}, \mathrm{Cd}$ and $\mathrm{Hg}$ transported by plankton from a contaminated area (Ria de Aveiro). Acta Oecologica 24, S351-S357.

OSPAR Commission, 2004. Mercury losses from the Chlor - Alkali Industry (1982-2002).

Pereira, M.E., Duarte, A.C., Millward, G., Vale, C., Abreu, S.N., 1998a. Tidal export of particulate mercury from the most contaminated area of Aveiro's Lagoon, Portugal. Science of the Total Environment 213, 157-163.

Pereira, M.E., Duarte, A.C., Millward, G., Abreu, S.N., Vale, C., 1998 b. An estimation of industrial mercury stored in sediments of a confined lagoon of Aveiro (Portugal). Water Science and Technology 37, 125 130 .

Ramalhosa, E., Monterroso, P., Abreu, S., Pereira, E., Vale, C., Duarte, A., 2001. Storage and exportof mercury from a contaminated Bay (Ria de Aveiro, Portugal). Wetlands Ecology and Management 9, 311-316.

Válega, M., Abreu, S., Pato, P., Rocha, L., Gomes, A.R., Pereira, M.E., Duarte, A.C., 2006. Determination of organic mercury in biota, plants and contaminated sediments using a thermal atomic absorption spectrometry technique. Water, Air and Soil Pollution 174, 223-234.

Verdelhos, T., Neto, J.M., Marques, J.C., Pardal, M.A., 2005. The effect of eutrophication abatement on the bivalve Scrobicularia plana. Estuarine, Coastal and Shelf Science 63, 261-268.

Vidal, D.E., Horne, A.J., 2003. Inheritance of mercury tolerance in the aquatic oligochaete Tubifex tubifex. Environmental Toxicology and Chemistry 22, 2130-2135. 
Watras, C.J., Bloom, N.S., 1992. Mercury and methylmercury in individual zooplankton: Implications for bioaccumulation. Limnology and Oceanography 37, 1313-1318.
Williams, P.R., Attrill, M.J., Nimmo, M., 1998. Heavy metal concentrations and bioaccumulation within the Fal Estuary, UK: a reappraisal. Marine Pollution Bulletin 36, 643-645.

\title{
Spatial and temporal variations of mercury in sediments from Victoria Harbour, Hong Kong
}

\author{
Jian-bo Shi ${ }^{\text {a }}$, Carman C.M. Ip ${ }^{\text {a }}$, Chole W.Y. Tang ${ }^{\text {a }}$, Gan Zhang ${ }^{\text {b }}$ \\ Rudolf S.S. Wu ${ }^{\mathrm{c}}$, Xiang-dong $\mathrm{Li}^{\mathrm{a}, *}$ \\ ${ }^{a}$ Department of Civil and Structural Engineering, The Hong Kong Polytechnic University, Hung Hom, Kowloon, Hong Kong \\ ${ }^{\mathrm{b}}$ State Key Laboratory of Organic Geochemistry, Guangzhou Institute of Geochemistry, Chinese Academy of Sciences, Guangzhou 510640, PR China \\ ${ }^{\mathrm{c}}$ Department of Biology and Chemistry, City University of Hong Kong, 83 Tat Chee Avenue, Kowloon, Hong Kong
}

Mercury $(\mathrm{Hg})$ is listed as a priority pollutant by many international agencies because of its persistence, bioaccumulation, and toxicity (PBT) in the environment. With the development of agriculture and industry, $\mathrm{Hg}$ has been extensively used in the manufacture of pesticides, fungicides, electrical goods, paper, batteries and other items, which has caused large amounts of $\mathrm{Hg}$ to be emitted to the environment.

The ocean is an important sink in the global $\mathrm{Hg}$ cycling. In recent years, the biogeochemistry of $\mathrm{Hg}$ in coastal and estuarial environments has received particular attention (Mason et al., 1996; Horvat et al., 1999; Hines et al., 2000; Conaway et al., 2003). Mercury enters the marine environment through various pathways, including wastewater discharges and atmospheric deposition. Two important processes are involved in the cycling of $\mathrm{Hg}$ in coastal and ocean environments. The first is the methylation of inorganic $\mathrm{Hg}$ to organomercury in water and sediment systems. This will affect the toxicity and bioavailability of $\mathrm{Hg}$. The second is the bioaccumulation of $\mathrm{Hg}$ in aquatic organisms through the food chain. This will result in higher methylmercury $(\mathrm{MeHg})$ concentrations in seafood, and may ultimately threaten human health.

Hong Kong is located on the southern coast of China and is made up of Hong Kong Island, the Kowloon Peninsula, the New Territories, and surrounding islands. The population of Hong Kong, about half of whom live on Hong Kong Island and in the Kowloon Peninsula, exceeded 6.9 million in 2005 (HK CSD, 2006). Hong Kong is also one of the busiest port-cities in the world. In the past few decades until recently, it had a thriving manufacturing industry. Because of the uncontrolled disposal of domestic and industrial wastewa-

\footnotetext{
* Corresponding author. Tel.: +852 2766 6041; fax: +852 23346389.

E-mail address: cexdli@polyu.edu.hk (X.-d. Li).
}

ter, especially from the 1960s to the 1980s, the coastal waters of Hong Kong have become seriously contaminated (Morton, 1989; Wong and Tanner, 1997; Blackmore, 1998).

Victoria Harbour is a major port of Hong Kong and lies between the highly urbanized and industrial areas of Hong Kong Island and the Kowloon Peninsula. The length and area of the harbour are $12 \mathrm{~km}$ and about $5000 \mathrm{ha}$, respectively (Morton, 1989). In the past, the wastewater from both sides was discharged directly into the harbour after simple screening (HK EPD, 2004). According to the government of Hong Kong, the harbour received an estimated $1.5 \mathrm{Mt}$ of sewage and industrial wastewater per day in 1995 (Hong Kong Government, 1995). In 1997, about $340 \mathrm{t}$ of total biochemical oxygen demand (BOD), $280 \mathrm{t}$ of total suspended solids, and $3 \mathrm{t}$ of toxic metals were discharged into the harbour every day (Yung et al., 1999). As a result, the harbour is heavily contaminated with bacteria (Yung et al., 1999), heavy metals (Tanner et al., 2000), and organic pollutants (Connell et al., 1998). Although some efforts at controlling the pollution have been made and the water quality has improved in recent years, high concentrations of $\mathrm{Hg}$ $(8 \mu \mathrm{g} / \mathrm{g})$ were still found in sediment from Victoria Harbour in 2004 (HK EPD, 2004). In addition, the distribution, especially the historical changes and species, of $\mathrm{Hg}$ in Victoria Harbour has thus far received little research attention.

The aim of this work was to study the spatial distribution and historical changes of $\mathrm{Hg}$ in sediments from Victoria Harbour. The concentration of $\mathrm{MeHg}$ in selected sediment samples was also be investigated.

A map of the study area and the locations of the sampling sites are shown in Fig. 1. Five sampling sites from east (B1) to west (B5) of Victoria Harbour were selected to provide good coverage of the harbour area and avoid regions with known sediment disturbances (e.g., dredged areas and environments adjacent to intensive reclamation activities). The geographic positions and depths of water 